\title{
The two shapes of the Tau protein
}

\section{Tau proteins can convert from an inert shape to a misfolded shape that seeds the growth of fibers that contribute to the pathology of Alzheimer's disease.}

\section{JEFFERY W KELLY}

Related research article Mirbaha $\mathrm{H}$, Chen D, Morozova OA, Ruff KM, Sharma A, Liu X, Goodarzi M, Pappu RV, Colby DW, Mirzaei H, Joachimiak LA, Diamond MI. 2018. Inert and seed-competent tau monomers suggest structural origins of aggregation. eLife 7:e36584. DOI: 10.7554/eLife.36584

M ost of the time, proteins fold into a single stable shape to perform their role in the body, but occasionally they can adopt a different conformation. These 'misfolded' proteins can be associated with a range of degenerative conditions known as amyloid disorders, which includes the transthyretin amyloidoses as well as Alzheimer's and Parkinson's diseases. This is because the misfolded proteins go on to stick together and form toxic insoluble aggregates, for example 'amyloid' fibers, that accumulate inside cells. One such protein is Tau, which aggregates in people with Alzheimer's disease. It is thought that the misfolded Tau proteins and the various Tau aggregates, including amyloid fibers, contribute to the onset of Alzheimer's disease (Eisele et alo, 2015), but these processes are not fully understood.

Inside a cell, the harmful aggregation process is believed to begin with a 'seed', a template that can trigger the assembly of a given protein. These seeds are thought to be crucial in the spread of the disease. The hypothesis is that seeds can convert the normally folded protein into an aggregate of the same protein, before cells release them into the environment for neighboring cells to take up (Eisenberg and Jucker, 2012). This could be how diseases linked to the Tau protein, such as Alzheimer's, propagate from one cell to another; there, the aggregates would travel through the brain using the connections between neurons (Clavaguera et alı, 2009; Sanders et al., 2014). While the identity of the seeds remains unclear, until now, almost all scientists have believed that they are an assembly of a given individual misfolded protein. Now, in eLife, Marc Diamond of the University of Texas Southwestern Medical Center (UTSW) and colleagues - including Hilda Mirbaha as first author - report the existence of a stable of form of an individual Tau protein that can start the aggregation process on its own (Mirbaha et al., 2018).

The fact that the seed may not be an assembly of a misfolded protein, but instead be a single protein - a monomer - with a different conformation had only been suggested twice before. In 2005, a study proposed that a change in the conformation of a Tau monomer had a critical role in triggering the process of aggregation (Chirita et al., 2005). And in 2011, it was hypothesized that the aggregation of the huntingtin protein, which is involved in another amyloid disorder known as Huntington's disease, could start with a single protein (Kar et al., 2011). However, in these two studies the monomer that could initiate the seeding process was not isolated and studied. Despite robust data 
interpretation, many in the scientific community dismissed the idea of monomeric seeds, reluctant to challenge the widely ingrained concept that they are instead an assembly of a misfolded protein.

So far, Tau was considered to be an intrinsically disordered protein - more like a flexible noodle than a protein with a well-defined and stable, three-dimensional structure (Schweers et al., 1994). Instead, Mirbaha et al. show that the Tau protein can fold into two distinct and fairly well-defined conformations. One of these shapes is stable, nontoxic and does not easily aggregate; the other acts as a seed and can help to convert another 'harmless' Tau monomer into a misfolded Tau that will form toxic aggregates by seeding or self-assembly. In addition, Tau can very slowly change from the inert to the seed-competent conformation. It is known that small molecules can bind to the inert conformation of proteins that are prone to misfolding, and thus prevent the conformational change that leads to amyloid diseases (Johnson et al., 2012).

For example, transthyretin is another protein with two ways of folding, and whose toxic conformation damages various nervous systems, as well as the heart. However, drugs known as kinetic stabilizers can slow down the degenerative process by increasing the population of the properly folded conformation. More precisely, three placebo-controlled clinical trials showed that small molecules, such as the drugs tafamidis and diflunisal, can bind to the non-pathogenic form of transthyretin and stabilize it, which prevents the protein from converting into the conformation that initiates aggregates and leads to degenerative pathologies (Coelho et alı, 2012; Berk et al., 2013; Rosenblum et al., 2018). This suggests that it should be possible to fashion similar kinetic stabilizers for the Tau protein, and offer better treatment for diseases such as Alzheimer's.

Jeffery W Kelly is in the Departments of Chemistry and Molecular Medicine, The Scripps Research Institute, La Jolla, United States

jkelly@scripps.edu

(iD) http://orcid.org/0000-0001-8943-3395

Competing interests: The author declares that no competing interests exist.

Published 10 July 2018

\section{References}

Berk JL, Suhr OB, Obici L, Sekijima Y, Zeldenrust SR, Yamashita T, Heneghan MA, Gorevic PD, Litchy WJ,
Wiesman JF, Nordh E, Corato M, Lozza A, Cortese A, Robinson-Papp J, Colton T, Rybin DV, Bisbee AB, Ando Y, Ikeda S, et al. 2013. Repurposing diflunisal for familial amyloid polyneuropathy: a randomized clinical trial. JAMA 310:2658-2667. DOl: https://doi.org/10. 1001/jama.2013.283815, PMID: 24368466

Chirita CN, Congdon EE, Yin H, Kuret J. 2005.

Triggers of full-length tau aggregation: a role for partially folded intermediates. Biochemistry 44:58625872. DOI: https://doi.org/10.1021/bi0500123, PMID: 15823045

Clavaguera F, Bolmont T, Crowther RA, Abramowski D, Frank S, Probst A, Fraser G, Stalder AK, Beibel M, Staufenbiel M, Jucker M, Goedert M, Tolnay M. 2009. Transmission and spreading of tauopathy in transgenic mouse brain. Nature Cell Biology 11:909-913.

DOI: https://doi.org/10.1038/ncb1901, PMID: 1 9503072

Coelho T, Maia LF, Martins da Silva A, Waddington Cruz M, Planté-Bordeneuve V, Lozeron P, Suhr OB, Campistol JM, Conceição IM, Schmidt HH, Trigo P, Kelly JW, Labaudinière R, Chan J, Packman J, Wilson A, Grogan DR. 2012. Tafamidis for transthyretin familial amyloid polyneuropathy: a randomized, controlled trial. Neurology 79:785-792. DOI: https:// doi.org/10.1212/WNL.0b013e3182661eb1, PMID: 22 843282

Eisele YS, Monteiro C, Fearns C, Encalada SE, Wiseman RL, Powers ET, Kelly JW. 2015. Targeting protein aggregation for the treatment of degenerative diseases. Nature Reviews Drug Discovery 14:759-780. DOI: https://doi.org/10.1038/nrd4593, PMID: 2633 8154

Eisenberg D, Jucker M. 2012. The amyloid state of proteins in human diseases. Cell 148:1188-1203. DOI: https://doi.org/10.1016/j.cell.2012.02.022, PMID: 22424229

Johnson SM, Connelly S, Fearns C, Powers ET, Kelly JW. 2012. The transthyretin amyloidoses: from delineating the molecular mechanism of aggregation linked to pathology to a regulatory-agency-approved drug. Journal of Molecular Biology 421:185-203. DOI: https://doi.org/10.1016/j.jmb.2011.12.060, PMID: 22244854

Kar K, Jayaraman M, Sahoo B, Kodali R, Wetzel R. 2011. Critical nucleus size for disease-related polyglutamine aggregation is repeat-length dependent. Nature Structural \& Molecular Biology 18 : 328-336. DOI: https://doi.org/10.1038/nsmb.1992, PMID: 21317897

Mirbaha H, Chen D, Morozova OA, Ruff KM, Sharma A, Liu X, Goodarzi M, Pappu RV, Colby DW, Mirzaei H, Joachimiak LA, Diamond MI. 2018. Inert and seedcompetent tau monomers suggest structural origins of aggregation. eLife 7:e36584. DOI: https://doi.org/10. 7554/eLife.36584

Rosenblum H, Castano A, Alvarez J, Goldsmith J, Helmke S, Maurer MS. 2018. TTR (Transthyretin) Stabilizers are associated with improved survival in patients with TTR cardiac amyloidosis. Circulation: Heart Failure 11:e004769. DOl: https://doi.org/10. 1161/CIRCHEARTFAILURE.117.004769, PMID: 2 9615436

Sanders DW, Kaufman SK, DeVos SL, Sharma AM, Mirbaha H, Li A, Barker SJ, Foley AC, Thorpe JR, Serpell LC, Miller TM, Grinberg LT, Seeley WW, Diamond MI. 2014. Distinct tau prion strains 
propagate in cells and mice and define different tauopathies. Neuron 82:1271-1288. DOI: https://doi. org/10.1016/j. neuron.2014.04.047, PMID: 24857020 Schweers O, Schönbrunn-Hanebeck E, Marx A, Mandelkow E. 1994. Structural studies of tau protein and Alzheimer paired helical filaments show no evidence for beta-structure. The Journal of Biological Chemistry 269:24290-24297. PMID: 7929085 